\title{
KOMPATIBILITAS KONSEP SUSTAINABLE DEVELOPMENT PADA LAPORAN CORPORATE SOCIAL RESPONSIBILITY
}

\author{
Sarah Yuliarini*, Titik Inayati \\ Universitas Wijaya Kusuma Surabaya, Indonesia
}

\section{OPEN ACCESS}

ISSN 2548-3501 (online)

Edited by:

Eny Maryanti

Correspondence sarahyuliarini@uwks.ac.id Received: 27 August 2021 Accepted: 5 January 2022

Published: 31 January 2022

Citation:Yuliarini dan Inayati (2022) Kompatibilitas Konsep Sustainable Development pada Laporan Corporate Social Responsibility
Intrinsic aspect that is owned by internal management on policies related to the corporation social responsibility (CSR) program leads to the results the company wants to achieve their purposes. Based on the context of intrinsic factors, this study intends to explore facts from the internal management of a company regarding the compatible concept for sustainable development (SD) as company achievements on CSR as a program that is run by the company. This research was conducted with a qualitative approach and strengthened by a triangulation process with supporting data from the company's Sustainability Report (SR). Monetary quantity parameter or economy aspect of corporate wealth (such as tangible assets be classified as internal features or extrinsic factor) have relatable impact to sustainable development (SD), with semantic analysis method revealed intrinsic factor have not it. The contribution to outcomes is to create a conceptual framework for categories associated with sustainable development through the CSR program that is required by the government for companies to implement in Indonesia. The implication of the research is found the CSR reporting supporting economic aspect, strengthen sustainable development in practices.

Keywords: Intrinsic aspect, Sustainable development, Corporation social responsibility, Semantic analysis,
Categories

Aspek intrinsik yang dimiliki manajemen internal terhadap kebijakan terkait program korporasi social responsibility (CSR) mengarah pada hasil yang diinginkan perusahaan untuk mencapai tujuannya. Berdasarkan konteks faktor intrinsik, penelitian ini bermaksud untuk mengeksplorasi fakta dari manajemen internal sebuah perusahaan mengenai konsep yang kompatibel untuk sustainable development (SD) sebagai pencapaian perusahaan pada CSR sebagai program yang dijalankan oleh perusahaan. Penelitian ini dilakukan dengan pendekatan kualitatif dan diperkuat dengan proses triangulasi dengan data pendukung dari Sustainability Report (SR) perusahaan. Parameter kuantitas moneter atau aspek ekonomi kekayaan perusahaan (seperti aset berwujud diklasifikasikan sebagai fitur internal atau faktor ekstrinsik) memiliki dampak yang berkaitan dengan sustainable development (SD). Metode analisis semantik mengungkapkan faktor intrinsic. Kontribusi terhadap hasil adalah menciptakan kerangka konseptual untuk kategori yang terkait dengan sustainable development (SD) melalui program CSR yang diperlukan bagi perusahaan untuk diterapkan di Indonesia. Implikasi dari penelitian ini ditemukan kompatibel pelaporan CSR masih terkait faktor ekonomi, yang berfungsi untuk memperkuat sustainable development dalam praktik 


\section{PENDAHULUAN}

Berkaitan dengan tanggung jawab lingkungan dan sosial korporasi, Indonesia memiliki peraturan dan kebijakan di daerah abu-abu, dalam arti masing-masing lembaga pengatur mengeluarkan kebijakan yang tidak saling mendukung secara jelas. Hal ini dipandang sebagai praktik sukarela yang berkaitan dengan masyarakat dan lingkungan. Hal itu terlihat dari standar akuntansi yang diterima secara umum (Statement of Financial Accounting Standards) nomor satu (1), ayat sembilan (9) yang menyatakan bahwa perusahaan tidak secara eksplisit melaporkan kegiatan tanggung jawab sosial perusahaan. Selanjutnya, PSAK memberikan kebebasan kepada perusahaan untuk mengungkapkan klasifikasi, pengukuran dan pelaporan CSR sesuai dengan kebutuhan masing-masing perusahaan. Sementara itu, secara hukum yuridis yang tertuang dalam Undang-Undang nomor 40 tahun 2007 pasal 66 ayat (2) tentang Perseroan Terbatas mewajibkan perusahaan untuk mengungkapkan kegiatan tanggung jawab sosialnya dalam laporan tahunan mereka. Fakta inilah yang membuat praktik CSR di Indonesia memiliki preferensi yang berbeda, termasuk format, konten, dan luasnya informasi tentang CSR.

Selain UU PT juga terdapat undang-undang yang lebih mengikat khusus untuk BUMN terkait implementasi CSR, yaitu KEP236/MBU/2003 tentang Program Kemitraan Badan Usaha Milik Negara dengan Usaha Kecil dan Program Pembangunan Masyarakat (PKBL), UU no 25 tahun 2007 pasal 15 (b) dan pasal 16 (d) tentang investasi. Oleh karena itu, penelitian mengambil data dari BUMN dengan status Perusahaan Perseroan.

Praktik sukarela berarti bahwa banyak perusahaan masih berusaha mencari manfaat dari kegiatan dalam CSR. Sustainable development didefinisikan sebagai kegiatan non-pasar yang terkait dengan organisasi swasta (atau publik yang diprivatisasi) dan berdampak pada lingkungan biofisik, di mana hal itu mempengaruhi analisis keputusan formal dalam mengantisipasi biaya sosial dan manfaat yang dilakukan sesuai dengan akuntansi manajemen tradisional (Mistry, Sharma dan Low (2014).

Yammeesri dan Herath (2010) menemukan bahwa isi pemikiran dan kebijakan direksi memiliki efek positif dan memiliki hubungan yang signifikan dengan nilai tegas, di sisi lain, ukuran direksi (ukuran) dan independensi direksi tidak berpengaruh pada nilai tegas. Ini memberikan pemahaman dasar bahwa parameter kuantitas fisik perusahaan (fitur internal atau faktor ekstrinsik) tidak mempengaruhi nilai eksternal perusahaan, melainkan faktor intrinsik yang berdampak pada sustainable development (SD) perusahaan (Joana dan Pedro (2015).

Faktor semantik yang dimiliki manajemen internal terkait kebijakan terkait program corporatation social responsibility (CSR) mengarah pada hasil yang ingin dicapai perusahaan secara umum. Oleh karena itu, penelitian ini berupaya menemukan kategori yang terkait dengan pengembangan manajemen internal yang berkelanjutan sebagai faktor semantik. Menemukan kategori apa pun yang memperkuat keberadaan nilai intrinsik akan memberikan pemahaman aktual tentang persepsi spesifik CSR perusahaan.

Berdasarkan teori TBL (triple bottom line), yaitu gerakan awal yang mendasari CSR berisi kegiatan keseimbangan aspek lingkungan, sosial dan ekonomi yang didorong oleh Spreckley pada tahun 1981. Teori ini berkembang dengan menambahkan faktor investasi (UNEP Inquiry (2017). Sehingga dalam hal ini ada 4 (empat) pelaku yang dikenal sebagai stakeholder kepada siapa kegiatan yang berkaitan dengan CSR mendorong untuk mendaftar. Kegiatan tersebut merupakan bagian penting dari mengkomunikasikan laporan CSR kepada pemangku kepentingan, dalam hal ini, pelanggan, pemasok, dan karyawan (Husser, Irgo, V, Andre dan Barbat (2012). Ditambah satu pemangku kepentingan yang juga pemegang saham, pemerintah jika perusahaan adalah BUMN (Burrit (2012); Yuliarini, Othman dan Ismail (2017). Muncul pertanyaan yang mendasari penelitian tentang cara mengukur aspek aktivitas dominan dalam setiap tahun sesuai dengan laporan tahunan yang diterbitkan oleh PT. SMGR Tbk yang ditujukan kepada para pemangku kepentingan. Pemilihan objek perusahaan didasarkan pada komitmen sebagai BUMN pertama yang menjalankan program carbon reduction dan perdagangan karbon 2013 hingga 2016. Kebijakan internal management ini menjadi pondasi komunikasi kepada pemangku kepentingan eksternal dalam menerapkan Triple Bottom Line. Berdasarkan keterangan latar belakang, penelitian ini berupaya mencari tahu bagaimana struktur komunikasi yang terkait dengan sustainable development berdasarkan konsep keberlanjutan dalam pelaporan CSR itu sendiri dan manajemen internal yang dirasakan pada istilah keberlanjutan adalah secara equivocal.

Manajemen Internal Dirasakan dalam Jangka Waktu
Keberlanjutan

Istilah keberlanjutan bukanlah pertanyaan yang kuat tentang nilai intrinsik alam atau pertanyaan lemah untuk menghasilkan peluang tetapi lebih dari pertanyaan pragmatis untuk melestarikan spesies kita. Sementara itu, Sholihin dan Madein (2015) menyatakan bahwa sustainable development bagi perusahaan terkait dengan kinerja ekonomi. Kinerja ekonomi tersebut terlihat pada unsur pengurangan sumber daya, fluktuasi energi, kewajiban produk, biaya kepatuhan, dan peningkatan citra perusahaan. Hal yang sama diungkapkan oleh Frankel dan Lee (1998) bahwa nilai intrinsik manajemen ditentukan oleh laju pertumbuhan periode berjalan dan laju pertumbuhan potensial di masa depan. Pertumbuhan periode berjalan menentukan kenaikan pendapatan (pendapatan) di masa depan, sementara tingkat pertumbuhan potensial akan datang dapat dipengaruhi dengan adanya pengurangan kerugian tambahan (incremental loss) sebagai penghambat aspek pertumbuhan. Mendeteksi kemungkinan adanya kerugian tambahan dilakukan untuk perbaikan pada periode berikutnya. Namun, keberlanjutan jangka panjang yang 
menggunakan pengukuran moneter saja tidak dapat menjawab hubungan mendasar antara pelaporan CSR dan kinerja perusahaan untuk bertahan dalam jangka panjang dan dalam periode krisis juga (Galant dan Cadez (2017). Diperlukan pengukuran kualitatif yang dapat menilai kesinambungan perusahaan dalam mempertahankan sustainable development.

\section{Sustainable Development (Pembangunan Berkelanjutan) dalam Triple Bottom Line Plus}

Mengenai leksikologi kesesuaian antara program (kegiatan) dan hasil (pelaporan CSR), itu menunjukkan struktur komunikasi yang seimbang (Mistry, Sharma dan Low (2012). Seimbang berarti pengelompokan, pengukuran, dan pelaporan kegiatan non-pasar memiliki nilai yang sama. Husser et.al (2012) mengukur kompatibilitas CSR dengan pelaporan standar di Prancis dari 40 perusahaan dan menemukan bahwa manajemen internal lebih menekankan pada proses pengelolaan untuk CSR, bukan pada aspek sustainable development. Kegiatan non-pasar merupakan aktivitas yang sering dikaitkan dengan faktor eksternalitas, yang menjadi penghalang kedua setelah tarif bagi perdagangan global (trade barriers). Hal ini yang perlu dikelola dan dikendalikan perusahaan agar bertahan dalam jangka panjang. Konkruensi kebijakan internal management dengan pengungkapan dalam pelaporannya menjadi sinergi yang mendukung komunikasi kepada pihak-pihak yang berkepentingan (makna yang tersirat dari yang tersurat).

Yuanita (2015) mengungkapkan bahwa sustainable development hanya dapat dicapai dengan adanya harmonisasi yang dilaksanakan perusahaan pada aspek-aspek ekonomi, sosial, dan lingkungan. Tambahan aspek investasi dikaitkan dengan dukungan penganggaran untuk kebijakan harmonisasi ini (UNEP Inquiry (2017). Hal ini memperkuat tujuan program CSR pada perusahaan sebagai bentuk promosi atas konsep sustainable development (Hopper, Lassou, \& Soobaroyen, (2017). Komitmen perusahaan dalam program CSR diharapkan mengacu pada integrasi business chain dengan aspek-aspek yang mendukung SD.

\section{Kerangka Kerja Konseptual Riset}

[Figure 1 about here.]

Gambar 1 menunjukkan konsep hubungan antara CSR sebagai program dan pembangunan berkelanjutan sebagai pencapaian ideal untuk kegiatan non-pasar. Tanggung jawab sosial perusahaan adalah program non-pasar yang dirancang untuk mengurangi risiko manajemen (Aldama, Amar dan Trostianki (2014).

Dalam mencapai hasil SD yang ideal, perlu adanya konsistensi program dan para pelaku yang menjalankan program, yaitu manajemen internal. Ini menimbulkan pertanyaan mendasar bahwa bagaimana aktor-aktor ini dapat menyusun komunikasi dalam persepsi mereka sebagaimana diuraikan dalam output CSR, yang dikenal sebagai Sustainability Reporting (SR). Arah komunikasi internal manajemen (internal management intention) dapat dieksplorasi dari titik berat atau fokus pelaporan pada aspekaspek triple bottom line.

\section{METODE}

Metode structural dipilih untuk mendapatkan ruang lingkup tema asosiasi dan kontras antarlinking yang ditemukan dalam data (narasi) (Saldana (2009). Menurut Barthes (1994), semua konten dapat dianalisis berdasarkan tingkat data yang berbeda yang dibedakan dengan artikulasi, yaitu tingkat tindakan dan tingkat narasi. Analisis struktural konten dalam setiap data adalah dalam bentuk laporan keberlanjutan yang diterbitkan oleh perusahaan P.T. SMGR Tbk.

Fase analisis semantik berdasarkan Mallery (1991) yang

1. Representasi teks untuk menciptakan makna terdalam dalam model teks.

2. Klasifikasi, klasifikasi relasional, konfigurasi kata-kata dalam model teks

3. Inspeksi, analisis menggunakan angka, grafis antarmuka untuk memeriksa model teks.

\section{Populasi dan Sampel}

Data ini menggunakan laporan tahunan yang diterbitkan dari 2012 hingga 2017. Berdasarkan konsekuensi data keikutsertaan perusahaan dalam perdagangan karbon pada 2013 hingga 2016 dan tujuan penelitian untuk memahami konsistensi komunikasi pada CSR yang dilakukan perusahaan guna mendukung kebijakan triple bottom line. Oleh sebab itu, data diambil satu tahun sebelum dilaksanakan dan satu tahun sesudah dilaksanakan kebijakan internal manajemen dan konsep SD dalam triple bottom line. Ada 2 (dua) klasifikasi sumber daya data, yang berasal dari faktor aktivitas berdasarkan teori triple bottom line, terkandung dengan aspek lingkungan, aspek sosial, aspek ekonomi (Spreckley (1981) dan aspek investasi yang diperkenalkan oleh Prinsip Investasi Bertanggung Jawab pada tahun 2010, dan faktor pemangku kepentingan berdasarkan Husser, Irgo, Andre dan Barbat (2012) yang terdiri dari pelanggan, pemasok, karyawan, dan Burrit (2012)] menambahkan pemerintah. Sehingga ada 16 kriteria, yaitu 1) customer-environment, 2) customer-social, 3) customereconomic, 4) investasi pelanggan, 5) pemasok-lingkungan, 6) pemasok-sosial, 7) pemasok-ekonomi,8) pemasok-investasi, 9) karyawan-lingkungan, 10) karyawan-sosial, 11) karyawanekonomi, 12) karyawan-investasi,13) pemerintahenvironmental, 14) pemerintah-sosial, 15) pemerintah-ekonomi, 16) pemerintah-pemerintah-investment.

Penelitian kualitatif ini didukung dengan menggunakan pengukuran grafis, untuk melihat struktur semantik yang terungkap dalam Laporan Tahunan PT. SMGR Tbk dari 2012 
hingga 2017. Tahun ukuran ditetapkan pada tahun 2012, terkait dengan dimulainya PT. SMGR Tbk melakukan strategi triple bottom line dengan memulai penandatanganan kerjasama alih teknologi dan perdagangan karbon dengan Jepang dan Uni Eropa pada 2013 hingga 2016. Faktor eksternalitas yang mendorong kebijakan perusahaan untuk memberikan perhatian pada aspek sosial dan lingkungan hidup.

\section{Teknik Analisis}

\section{Tabulasi Semantik}

Dengan menggunakan tabulasi setiap kategori dihitung nilai rata-rata konsistensi semantik. Dalam Table 1, dapat dilihat bahwa nilai kategori mendekati $50 \%$ yaitu nilai rata-rata konsistensi 41,90\% terdiri dari 4 kategori dalam aspek komunikasi, yang nilai kemunculan aspek komunikasinya ada pada faktor ekonomi.

\section{[Table 1 about here.]}

\section{Analisis Grafik}

Namun, ada tahap inspeksi untuk menciptakan makna saturasi dalam konteks menggunakan analisis grafis. Dari hasil di atas, grafik yang diilustrasikan pada Gambar 2 menggunakan bagan batang, dapat dilihat bahwa perusahaan yang menggunakan Laporan Tahunan dari 2012 hingga 2017 secara konsisten menempatkan fungsi karyawan dan pelanggan dengan alokasi kegiatan, terutama ekonomi dan sosial. Ini sangat berbeda dari tujuan laporan CSR yang diungkap oleh Aldama, Amar dan Trostianki (2014) seharusnya untuk melaporkan kegiatan nonpasar. Kecenderungan konsistensi semantik ditunjukkan jika ukuran persentase di atas 50\%. "Jumlah sumbu yang dipilih ditentukan oleh ketika varians kumulatif yang dijelaskan melebihi 50 persen dari total varians" (Husser et al (2012).

Penelitian ini untuk melihat kecenderungan konsistensi semantik dalam struktur komunikasi yang digunakan oleh manajemen internal dalam mengekspresikan strategi TBL. Penelitian kualitatif ini didukung dengan menggunakan pengukuran grafis, untuk melihat struktur semantik yang terungkap dalam Laporan Tahunan PT. SMGR Tbk dari 2012 hingga 2017.

Dapat dilihat bahwa perusahaan mencoba memaksimalkan kegiatan karyawannya (Gambar 2, skornya antara 50 hingga 200) untuk mendukung strategi perusahaan, terutama pada faktor ekonomi dan sosial, diikuti oleh investasi dan kegiatan lingkungan. Demikian juga fokus perusahaan adalah pada aspek pelanggan. Artinya perusahaan masih memfokuskan upaya CSR pada customer oriented (Gambar 2 dengan skor 50 hingga 150), dibandingkan dengan government interest oriented yang juga merupakan pemegang saham terbesar untuk PT. SMGR Tbk diberikan porsi perhatian di posisi ketiga (Gambar 2), skornya antara 50 hingga 100.
[Figure 2 about here.]

Namun, ada tahap inspeksi untuk menciptakan makna saturasi dalam konteks menggunakan analisis grafis. Dari hasil di atas, grafik yang diilustrasikan pada Gambar 2 menggunakan bagan dapat dilihat bahwa perusahaan yang menggunakan Laporan Tahunan dari 2012 hingga 2017 secara konsisten menempatkan fungsi karyawan dan pelanggan dengan alokasi kegiatan, terutama ekonomi dan sosial. Ini sangat berbeda dari tujuan laporan CSR yang bertujuan untuk melaporkan kegiatan non-pasar (Mistry, Sharma dan Low (2014).

Perkembangan berkelanjutan perusahaan yang diungkapkan dalam CSR lebih difokuskan pada penguatan pasar karena alasan ekonomi dan menunjukkan kemampuan perusahaan yang didukung penuh oleh karyawannya.

\section{HASIL DAN PEMBAHASAN Orientasi Pelanggan-Ekonomi}

Fokus perusahaan adalah dalam aspek pasar dengan mempertimbangkan kondisi jangka panjang. Hal ini dinyatakan dalam kalimat dalam Laporan Tahunan bahwa pertumbuhan mikro jangka panjang sebuah perusahaan tergantung pada kondisi makro nasional. "Peningkatan pertumbuhan ekonomi nasional yang berkelanjutan pada akhirnya akan memberikan manfaat bagi bisnis semen dalam jangka panjang." (Laporan Tahunan PT SMGR Tbk, 2015).

\section{Orientasi Pelanggan-Sosial}

Manajemen internal mencoba menekankan nilai perusahaan. Agbejule (2011) menyatakan bahwa budaya perusahaan memiliki pengaruh pada kinerja perusahaan. Memberikan relevansi pelanggan dengan nilai-nilai sosial yang diusung perusahaan merupakan salah satu strategi untuk memperkuat pasar. Laporan Tahunan mengungkapkan bahwa perusahaan menyediakan layanan purna jual dan survei pasar tentang kepuasan pelanggan, serta pengadaan program khusus "SI PEDULI". Berupa dukungan perusahaan terhadap masyarakat sekitar terkait pengembangan UMKM. Hal ini menjadikan aspek sosial sebagai sub-kategori untuk aspek ekonomi dari laporan CSR perusahaan.

\section{Orientasi Ekonomi Pemasok}

Perusahaan telah mengungkapkan sistem rantai pasokan dalam laporan CSR. Hal ini membuktikan bahwa kepedulian perusahaan terhadap ketepatan waktu dan target produksi, meskipun mereka mengampuni usaha dalam program CSR.

\section{Orientasi Karyawan-Ekonomi}

Kategori kegiatan ekonomi yang terkait dengan karyawan terkait dengan tujuan perusahaan untuk meningkatkan manfaat ekonomi dari setiap tahap atau proses yang memungkinkan aspek sosial-lingkungan di dalamnya. Ada alokasi sumber daya 
manusia yang berhubungan khusus dengan, seperti mengendalikan aset yang telah diganti, dan memanfaatkan limbah.

\section{Orientasi Pemerintah-Ekonomi}

Meskipun pemerintah adalah pemegang saham terbesar (51\%), perusahaan tidak menempatkan pemegang saham sebagai subjek utama untuk melakukan pembangunan berkelanjutan. Peran pemerintah penting bagi perusahaan, tetapi hanya sebagai regulator yang membantu dalam memperkuat sektor makro.

\section{Orientasi Pemerintah-Sosial}

Perusahaan yang dipelajari adalah 51\% milik negara dengan mengikuti aturan sebagai perusahaan yang terdaftar di bursa saham. Terlepas dari peran pemerintah dalam sektor makro, pemerintah mengendalikan aspek non-moneter melalui peraturan perundang-undangan Pasal 1 Angka 3 UndangUndang Nomor 40 Tahun 2007, yang mengharuskan perusahaan menyiapkan laporan CSR. konten dan tujuan pelaporan. Kegiatan pembangunan berkelanjutan lebih cenderung pada aspek ekonomi dan sosial, yang tentu saja mengarah pada nilai pasar. Namun, praktik tersebut telah memperkuat keberlanjutan perusahaan itu sendiri di pasar. Program CSR yang menumbuhkan empati perusahaan terhadap lingkungan, menghindari kondisi bahaya

lingkungan yang dalam jangka panjang akan berdampak pada perusahaan. Selain itu CSR berfungsi untuk memperkuat manajemen internal. Karyawan dan pemimpin perusahaan memiliki ikatan sosial yang tidak hanya terkait dengan produktivitas lini bisnis tetapi juga timbul perhatian karyawan terhadap rasa kebutuhan yang manusiawi. Rasa bangga ini memberi mereka kenyamanan dalam mendukung perusahaan pada akhirnya berdampak pada peningkatan kinerja produktivitas perusahaan.

Penelitian selanjutnya adalah dapat menggunakan metode yang sama untuk semua perusahaan yang melakukan pelaporan CSR dan mengambil nilai rata-rata untuk melihat vokal yang sama dari tujuan CSR secara teori yaitu mengungkapkan kegiatan non-pasar dan mengeksplorasi dampak praktik dengan usia korporasi. Ini bisa mendapatkan bukti luas bahwa konten CSR digunakan oleh perusahaan untuk strategi memperluas pangsa pasar dan strategi perusahaan jangka Panjang. Penelitian dapat dikembangkan dengan metode kuantitatif dengan analisis isi (content analysis) menggunakan indeksasi.

\section{KESIMPULAN}

Pelaporan CSR untuk kasus perusahaan ini secara individual mencerminkan legitimasi internal manajemen dalam menentukan konten dan tujuan pelaporan. Kegiatan pembangunan berkelanjutan lebih cenderung pada aspek ekonomi dan sosial, yang tentu saja mengarah pada nilai pasar. Namun, praktik tersebut telah memperkuat keberlanjutan perusahaan itu sendiri di pasar. Program CSR yang menumbuhkan empati perusahaan terhadap lingkungan, menghindari kondisi bahaya lingkungan yang dalam jangka panjang akan berdampak pada perusahaan. Selain itu CSR berfungsi untuk memperkuat manajemen internal. Karyawan dan pemimpin perusahaan memiliki ikatan sosial yang tidak hanya terkait dengan produktivitas lini bisnis tetapi juga timbul perhatian karyawan terhadap rasa kebutuhan yang manusiawi. Rasa bangga ini memberi mereka kenyamanan dalam mendukung perusahaan pada akhirnya berdampak pada kinerja produktivitas perusahaan meningkat.

\section{REFERENCES}

Agbejule, A. 2011. Organizational Culture and Perfomrmance: The Role of Management Accounting System. Journal of Applied Accounting Research12[1].Pp.74-89.

Aldama, LR. P., Amar, PA., Trostianki, DW. 2014. Embedding Corporate Responsibility Through Effective Organizational Structures. Corporate Governance: The International Journal of Business in Society 9[4]. Pp.506-516.

Barthes, R. 1994. The Kitchen of Meaning. The Semiotic Challenge.Berkeley, CA: University of California Press Pp. 157-9 (translated by Richard Howard).

Burritt, R. L.2012. Environmental Performance Accountability: Planet, People, Profits. Accounting, Auditing \& Accountability Journal 25[2]. Pp.370-405.doi: $10.1108 / 09513571211198791$.

Frankel, R., C.M.C. Lee.1998. Accounting Valuation, Market Expectation and CrossSectional Stock Return. Journal of Accounting and Economic 25[3]. Pp. 283 - 319.

Galant, A., Cadez, S.2017. Corporate Social Responsibility and Financial Performance Relationship: A Review Of Measurement Approaches. Economic ResearchEkonomska Istraživanja 30[1], 676-693. doi:10.1080/1331677X.2017.1313122

Hopper, T., Lassou, P., \& Soobaroyen, T. (2017). Globalisation, accounting and developing countries. Critical Perspectives on Accounting, 43, 125-148. https://doi.org/10.1016/j.cpa.2016.06.003.

Husser, J., Irgo, M. I. V, Andre, J., Barbat, G. 2012. CSR And Sustainable Development: Are The Concepts Compatible? Management of Environmental Quality: An International Journal 23[6]. Pp. 658-672.

Joana S, Pedro N. 2015. When Corporate Social Responsibility Increases Performance: Exploring the Role of Intrinsic and Extrinsic CSR Attribution, Business Ethics A European Review 24[2]. Pp. 111-124. doi.org/10.1111/beer.12084.

Malleri JC. 1991. Semantic Content Analysis: A New Methodology for The Relatus Natural Language Environment, in in Articial Intel ligence and International Politics, editor, Valerie M. Hudson. Boulder: Westview Press.

Mistry, V., Sharma, U., Low, M. 2014. Management Accountants' Perception of Their Role in Accounting for Sustainable Development: An Exploratory Study. Journal of Global Mobility 2[3]. Pp, 343-374.

Saldana, J. 2009. An Introduction to Codes and Coding. In The Coding Manual For Qualitative Researchers. Los Angeles, CA: Sage.

Sholihin M., Madein A.2015. The Impact of Social and Environmental Information on Managers' Decisions: Experimental Evidence from Indonesia. Asian Review of Accounting June 32. Pp.156 - 169. doi:10.1108/ARA-11-2013-0074

Yammeesri, J., Herath, S.K. 2010. Board Characteristics And Corporate Value: Evidence from Thailand" International Corporate Governance. The International Journal of Business in Society 10[2]. Pp. 279-292.

Yuanita, N. (2015). Key Policies for Sustainable Finance Indonesia Financial Services Authority ( OJK). Rapat Sosialisasi Industri KLembaga Keuangan dan Perbankan.

Yuliarini, S., Othman, Z., Nor, K., \& Ismail, I. 2017. Environmental Accounting Practices: A Regulatory and Internal Management Perspective. Journal of Ecconomic \& Financial Studies 5[3]. Pp. 1-11.

UNEP Inquiry. (2017). Green Finance Progress Report, (July). Retrieved from http://unepinquiry.org/wp-

content/uploads/2017/07/Green_Finance_Progress_Report_2017.pdf

ConflictofInterestStatement: The authorsdeclare that theresearch wasconducted in the absence of any commercial or financial relationships that could be construedas a potential conflict of interest.

Copyright (C) 2022 and. This is an open-access article distributed under the terms of the Creative Commons Attribution License (CC BY). The use, distribution or repro-duction in other forums is permitted, provided the original author(s) and the copy-right owner(s) are credited and that the original publication in this journal is cited, in accordance with accepted academic practice. No use, distribution or reproduction is permitted which does not comply with these terms. 


\section{LIST OF TABLES}

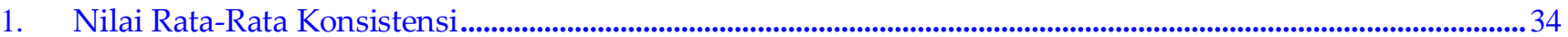


TABLE1 $\mid$ Ringkasan Prosedur Pemilihan Sampel

\begin{tabular}{ccccc}
\hline value & $\begin{array}{c}\text { Environ } \\
\text { ment }\end{array}$ & Social & Eco. & Invest \\
Customer & 41.62 & 64.91 & 112.21 & 42.57 \\
$\%$ & 15.98 & 24.8 & $\mathbf{4 2 . 9 5}$ & 16.28 \\
Supplier & 7.83 & 11.5 & 21.53 & 8.05 \\
$\%$ & 16 & 23.5 & $\mathbf{4 4}$ & 16.45 \\
Employee & 66.95 & 111.1 & 183.93 & 69.67 \\
$\%$ & 14.44 & 23.96 & $\mathbf{3 9 . 6 7}$ & 15 \\
Government & 25.1 & 47.92 & 68.82 & 26.04 \\
$\%$ & 14.95 & 28,54 & $\mathbf{4 0 . 9 9}$ & 15.5 \\
Rata-rata & $15.34 \%$ & $25,20 \%$ & $\mathbf{4 1 , 9 0 \%}$ & $15,80 \%$ \\
\hline
\end{tabular}




\section{LIST OF FIGURES}

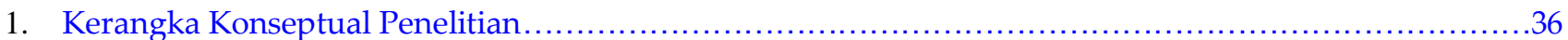

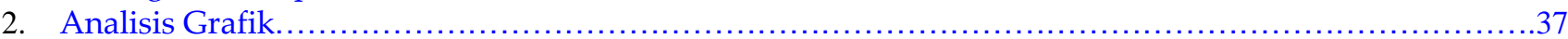


FIGURE 1 | Kerangka Konseptual Penelitian

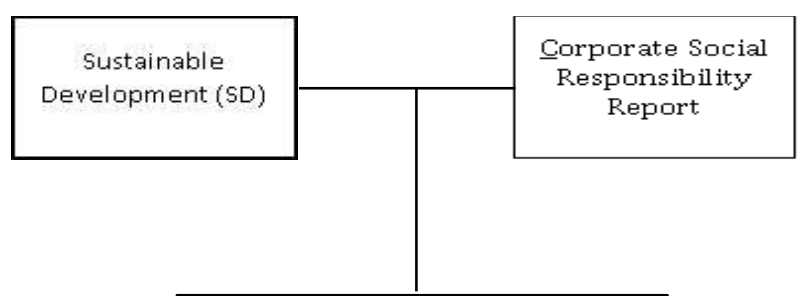

Internal management intention in Sustainability Reporting 
FIGURE 2 | Analisis Grafik

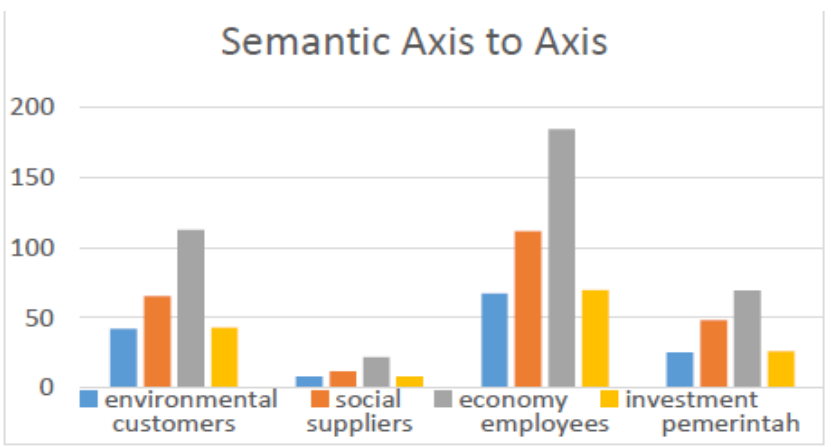

